\title{
Administration of National Integration in Nigeria: The Challenges and Prospects
}

\author{
Etim O. Frank \\ Department of Political Science, University of Uyo, Akwa Ibom State, Nigeria \\ E-mail: frankokonet@yahoo.com \\ Wilfred I. Ukpere \\ Department of Industrial Psychology and People Management, Faculty of Management, \\ University of Johannesburg, Johannesburg, South Africa \\ E-mail: wilfredukpere@gmail.com
}

Doi:10.5901/mjss.2013.v4n14p481

\begin{abstract}
This paper examines the administration of national integration in Nigeria. It describes the concepts and identifies the principles associated with the exercise. It approaches the subject by operationalizing through the content analysis paradigm and submits that the two greatest tolls of integration remain state and nation-building. It posits that since the military has had the greatest influence in Nigeria's socio-political development, the military elite corps pursued it through the measures outlined in the section, empirical steps of the paper. It however identifies a factor which militates against integration in the Nigerian state. In spite of these, the paper expresses the optimism that the introduction of certain norms and values and the respect of these norms by all the integrating units would certainly give birth to an organic Nigerian state. This is on the condition of purposeful leadership.
\end{abstract}

Keywords: Development, Integration, nation-building, normative standards, State

\section{Introduction}

A discourse of this nature does not require any geographical description of the entity- Nigeria. This is because Nigeria has assumed a position of recognition in global politics, though she is not a possessor of nuclear power. Considerable anthropological description of Nigeria had been conducted by the Michael Crowder, Evans-Pritchard, Lucy Maire and Thomas Hodgkin's of this world. What is however important to reaffirm at this level, in order to lead the discourse into the crux of the matter is to reiterate that before 1914, Nigerians were living separately in their various Kingdoms and Empires, many of which were under powerful rulers, while some others were under acephalous power structure. The social aggregate which metamorphosed into Nigeria included the Oyọ, Kanem Borno Empires, Bonny and Benin Kingdoms and many others (Rotberg, 1964; Ekundare, 1975; Coleman and Roseberg, 1966). These people had very little interaction, hence saw one another as strange bedfellows when brought together during the colonial exercise.

By 1861 the British colonial elements overran King Kososko of Lagos and established the 'Lagos colony'. The superior fire power of the colonialist soon created the southern and northern protectorates respectively (Ekundare, 1975). This marked the cradle but not in absolute terms of the interaction between the people of the West, East and North and the minority groups who were subsumed within the larger ethnic contraptions. 1922 (Hugh Clifford constitutional discourse) marked the epoch in which the different groups trapped within the entity called Nigeria, met formally for the first time to commence the process of national integration which was inadvertently encouraged by the colonial authority. It should be recalled that the processes of state formation often imply some element of compulsion, power and authority (Elaigwu 1981, cited in Ikara and Adjayi (1981), which has made the 'need for' and the 'how of' integration become problematic. It could therefore be postulated that the crisis of both 'state and nation-building in the Nigerian state, emanated from this fundamental flaw otherwise termed 'the short-cut' to integration.

Nigerians, hitherto as aforementioned, lived separately with minimal interaction. Bringing them into one entity in 1914 smacks a violation of the principles of social integration which needed the various people of Nigeria to set out the memorandum of oneness which would be captured in the Politea-the constitution even if unwritten. The approach to social integration demands negotiation and other details as defined in the administrative law which sets the basic 
structures and offices to be occupied and how to occupy same in turn, defines offices necessary to achieve the happiness of all which is the purpose of the state in the view of Aristotle (Esikot 2010). In the absence of this, which is a flagrant violation of integration processes and principles, a calamitous outcome could be preordained.

\section{Problem Statement}

Recently, there have been speculations that if care is not taken, Nigeria may disintegrate in the next $15-25$ years. This speculations may not be confidently disputed owing to the fact the political elite-corps, right from time immemorial, seems to have violated the principles of national integration.

\section{Research Questions}

The above statement led to the following research questions:

- How can Nigeria administer national integration in a way that she can avoid the reality of the above speculations?

- How has national integration in Nigeria been administered in Nigeria and how successful has it been?

- Has national integration been administered in such a way that no one feels unjustly treated?

- What then constitute the 'modus- operandi of true national integration?

\section{Research Objective}

The aim of this paper is to examine the nature of the administration of national integration in Nigeria and evaluate how it had been done, highlighting the challenges before Nigeria's march towards becoming an organic state.

\section{Scope and Outline of the Paper}

The paper is organized into various sections. The first section is the introduction leading to the statement of the problem, research question and objectives. The second section examined conceptual issues and the theoretical framework, while the third section examines the empirical steps that have been taken. Section four addressed the challenges to national intergration in Nigeria, while section five postulates the prospects towards the evolution of an organic state in Nigeria.

\section{Theoretical Framework}

Integration has been severally conceptualized. One of which is that regional integration is a process in which states enter into a supranational regional organization in order to increase regional cooperation and diffuse regional tension (Onwuka, 1982). In economic terms, it focuses on removing barriers to free trade in the region, increasing the free movement of people, labor, goods and capital across national borders, reducing the possibility of regional armed conflict through confidence and security -building measures, and adopting positions which enhances common stand on policy issues. This is aimed at generating economic advantages to individuals, states and regions (Balassa, 1961; UNECA, 2004). Extrapolating this conception to national integration, it would first mean 'state-building', that is the processes in which the different people in a state transfer primordial allegiance to one central authority, which becomes the representative of the people, who take conscious steps towards nation-building. Nation building would then involve the various processes by the central authority (state-building) causes the composite social group to cohere and regard one another as member in the same state with obligation towards one another.

Regional integration involves a process of increasing interaction and interdependence in the economic and political arena among a group of countries. The extensive body of literature on economic integration has its roots in the world that coincided with the beginning of the European Community, and even pre-dated it (Balassa, 1961, Tinbergen, 1954). Amitai Etzioni on the other hand upheld that integration may be defined as a condition identified with a set of vague symbols or variables, or as 'process' identified with an over-increasing degree of structural linkages between two or more parts of a system or systems (Onwuka, 1982).

There are three main approaches to the management of integration. These are Functionalist, Neo-Functionalist and Federalist. However, for the purpose of this paper, neo-functionalist paradigm would be applied. The Functionalist thesis is that since the critical function of any political community is security and welfare, it follows that if a moderate 
sufficiency of what the people want and ought to have is given to them, they will keep peace (Mitrany, 1975). In view of this, when an organization is set up to meet these needs of the people, their loyalty would incrementally shift to the organization rather than to the nation-state system.

The Neo-functionalist on the other hand upheld that the development of 'world Government' that is one supreme body for all states and people, is feasible through the growth of supranational organization (Ray, 1979). They upheld further that the efficiency and the effectiveness of the supranational organizations, in providing structural services to people in different states, however, in the same region, would ultimately lead to the shift of the people's allegiance away from their government to the organization and bureaucrats who now meet their needs. This is the approach adopted and applied by the European Union (EU) (Ray, 1979).

However, in addressing the problem posed, the orientation of this paper would include applying the principles of integration in internal integration of hitherto separate peoples. Thus this paper translates the principles of removing barriers between people, and the recognition of one central authority for all, to the processes of state and nation-building respectively. Consequently, the approach would involve examining the administration of integration in the Nigerian state against the backdrop of the 'principles of integration. The appreciation of the keywords 'state and nation-building' is germane to understanding the challenges posed by the concept. Nation-building refers to the lateral or horizontal processes by which different people in a political community decide to cohere together because they have found themselves in the same state (Elaigwu, 1981). The different nations in the state share functional responsibility and live interdependently with one another in harmony.

Integration has been subjected to a myriad of interpretations, but one of the most consistent elements conveyed by the term remains 'bringing together of different parts into a whole'. In this context the administration of national integration in Nigeria would refer to the processes of bringing the various Nigerian ethnic groups to cohere, on a continuing basis. It is the opinion of the present researchers that cohering often involves the development of cherished norms and values respected by all the cohering groups, in order to enable all component parts in the integration process to continue to have a sense of belonging to the political community created, not out of 'social-contract' through the colonial process of integration. This view was supported by (Burke and Mistre, 1968) when they both stressed the 'idea that a society is like an organism, the parts of which are in a natural balance that should not be disrupted by arbitrary innovations derived from abstract reasoning' (Burke and Mistre, 1968). Donald Levine in his piece on cultural integration 'contended that "administrators and reformers have been guided by the concept in their efforts to find innovations and modes of introducing change which fits most comfortably into existing cultures" (cited in Burke and Mistre, 1968). It is discernible at this point that national integration as a process, involves continuous adjustments of elements that would lead to a more or less coherent pattern of social interactions. National Integration should be seen by the people as the means of deriving both economic and political advantages. Thus, every group of participants should be ready to give and take. This is what takes place when states enter into supranational regional organizations in order to increase regional cooperation and diffuse regional tensions. The administrative processes consist of the actions involved in effecting the intent or desire of government towards national integration. It is thus the continuous active 'business' part of government, which is concerned with executing the law, as made by the legislative bodies (or other authoritative agents) and interpreted by courts, through the processes of organization and management, (Waldo, 1968) for national integration. Implicit in this conception are the issues of intent or desire to set up administrative processes, which conduces to both vertical and lateral integration of the Nigerian state; and continuously ensure that the public sector management achieves this.

\section{Rhetorical Issues}

The colonial authority had a mission and the absence of genuine attempts at integration is understandable against this background. The absence of socio-national integration amongst the various Nigerian people was therefore a sine-quanon for the realization of the goals of the colonialist. This position was corroborated by Ray (1979). There is a need to trace whether there was desire and intent to integrate when the baton of political leadership changed hands, how it was conducted and the problems that emanates from the process.

The extrapolation of regional integration principles as stated above, to the level of national integration, would involve the processes in which hitherto different people enter into a political community, in order to be able to obtain for themselves those things they could not individually possess. As earlier mentioned, efforts towards integration often involve:

i) the removal of the barriers to free trade and interactions; 
ii) confidence and security building measures (that is both state and nation-building processes);

iii) creation of appropriate enabling environment for economic, political, social and cultural interaction;

iv) the development of infrastructures in support of economic development;

v) development of strong public sector institutions and good Governance;

vi) the reduction of social exclusion and the development of inclusive civil society (Waldo, 1968).

vii) peace, security and financial contribution to balance centripetal and centrifugal forces.

In the next section, we shall evaluate the empirical administration of these principles in national integration, in Nigeria.

\section{Empirical Administration of National Integration in Nigeria}

A discourse on the empirical steps taken towards national integration in Nigeria would be more meaningful if the political sociology of Nigeria before the formal commencement of the process is outlined. This would elucidate the degree of integration already attained. It would be recalled that one of the foremost institutions established for an Independent Nigeria is the Nigerian Army. Recruitment into the army had been shared in the ratio of 50:25:25 for the North, East and the West respectively (Dudley 1978). This ratio perhaps exists till this day. This explicates the preponderance of northerners in command positions in the Nigerian military.

The obnoxious resource control issue has made the South-South region the most underdeveloped region in the country, yet the producer of the nation's wealth. This irony of a region constitutes a challenge to national integration in Nigeria. The political history of Nigeria indicates the fact that between the civil Democratic Government and the Military, it is the military which has traversed the political landscape much more like a troubadour with the greatest impacts in Nigeria (Elaigwu 1979). The first civil Democratic Government which took over governance from the colonial masters unknowingly forged national integration in Nigeria through the formation of the Government of alliance/Government of national unity, between the Northern People's Congress (NPC) and the National Council of Nigerian Citizens (NCNC). A marginal sense of belonging was thus created for the people of the Eastern region in 1966; this dialectically marked the cradle of the processes of national integration in Nigeria.

Before now the regions were stronger than the federal center by virtue of the Revenue Allocation Formula as contained in the constitution. Hence, the first step of the military which emerged in 1966 was to consolidate power at the center thus rendering the regions weak, which had exerted considerable power in the period 1960-66, of decree No. 1 , 1966 (Decree. 1966). By this decree, legislative and executive powers of the regions were dissolved. The Federal Military Government assumed 'power to make law for the peace, order and good government of Nigeria or any part thereof with respect to any matter (Decree. 1966). This started the processes of state-building described as steps taken by which the central (or federal) government of a sovereign state, makes its presence felt among the citizens by penetrating and controlling sub- national political and/or administrative units. It is the ability of the central or federal government to maximize or at least, increase its authority by the use of certain institutions of penetration and control; bureaucracy, political, party and/or the military (Almond, 1966). In furtherance of this, the federal government divided spheres of operation for the purposes of integration into exclusive, concurrent and residual lists. This engendered confidence building among Nigerians with central leadership to which everyone looked thereto. Nigerians in the West-East and the north henceforth have central focus of political leadership (Elaigwu 1981).

The Eastern region of Nigeria was never homogenous as the minority ethnic groups expressed fear of domination by the majority ethnic group. In fact the 1958 Willink Commission ordered by Her Majesty's Government had confirmed this fear in its 1959 report. The fears of the minority groups were assuaged in May 27, 1967, when Gowon declared a state of emergency, assumed all powers and created twelve states out of the four (4) regions (Elaigwu 1985). The creation of states according to Lt. Col. Gowon (as he was then titled) was 'to correct the imbalance in the administrative structure of the Country and to minimize future political friction and ensure a stable Federation (Elaigwu, 1982). This made the center stronger while immobilizing the regions and states from threatening the center any longer. A degree of integration was thus attained.

By 1968 administrative structures were established in the various states created in 1967. Governors were appointed who were indigenes of the various states. This processes of national integration strengthened unity and faith of all except the rebels in the Nigerian state (Elaigwu (1981). The Federal government also took over the funding of secondary and primary education which was initially in the residual list, while University education was moved from concurrent to the exclusive legislative list for uniformity and access to it by every Nigerian (Elaigwu 1981). The bringing of people of various backgrounds together in the Universities and similar institutions created awareness and dissolve 
prejudices which earlier existed. By the promulgation and implementation of decree No. 7 of February 24 1975, "Income Tax' amendment, every person in the country was subjected to uniform tax subject to the grade in which he/she belonged. The states unlike the regions in which they were carved out, became dependent on the Federal Government for their fiscal prowess. This centripetal force introduced, weakened the states vis-à-vis the federal government (Elaigwu, 1981). This has remained the position till this day. In addition, the states' Coat of Arms, which gave a semblance of autonomy, was abolished. All television stations were taken over by the federal government. While a council of state was established to create opportunity for dialogue between the Federal and state governments (Elaigwu, 1981).

It is pertinent to assert here that the various military moves as outlined, have not only transformed Nigeria from a 'mere geographical expression, but has turned it into an organic and integrated state. Intergovernmental relations also defined by the military regimes as federalism was instituted as a form of interaction for all tiers of government (Jemibewon, 1998). At the dawn of 1977-78 the ban on political activities was lifted. Principal among the conditions for the registration of any organized group of citizens who hold similar political opinion and who work to get control of government so that the policies they are interested to pursue be recognized as a political party, it must have effective presence in at least $2 / 3$ of the states in the federation. This was indeed another step intended to integrate the various people in Nigeria. These structures of state and nation-building by the military were able to bring Nigerians together under a central governmental authority. What were the challenges in driving this phenomenon?

\section{The Challenges to National Integration}

It is instructive to note that the subject of discourse, namely 'national integration' is referred to as organic solidarity by Emile Durkheim as integration through interdependence; where the parts of the whole reciprocate services as do the parts of an organism. It is discernible from Durkheim's thesis on social integration that division of labor, which is usually considered only an economic fact, is also a moral fact (Durkheim, 1968). Duties spring from the exercise, not just the duties specified in a contract, but the legitimate expectations with respect to means, quality of performance and the like. What then are the challenges which impede national integration in Nigeria? One of the greatest challenges to integration in the Nigerian state is the Niger-Delta question. The principle and theory of integration demand the removal of barriers to integration. Put differently, it means equating or ensuring the development of all parts in the integration equation. But the case of this region, poses the greatest challenge. This is explicable by the assertion of Darah (2012) when he stated that in 1958 the allocation of revenue from mining rents and royalties was in order of $50 \%$ to the area where a mineral was mined, $20 \%$ to the central government and $30 \%$ to a Distributable Pool Account. The region that earned the $50 \%$ also shared in this 30\% on the basis of equity. This progressive provision was included in the constitutions of 1960 and 1963 (Darah, 2012). However, this principle has been distorted in the present allocation formula, hence the region or zone which produces the wealth of the nation, now seem to receive the least governmental intervention. This situation has led to militancy and the quest for 'resource control' which may deny other regions of enormous resources they currently enjoy while contributing minimally to the wealth of the nation. Differential levels of development which constitute the problem of regional integration in Africa, has the same effect to national integration in Nigeria.

According to the Durkheim's postulate the principles of interdependency should balance both centripetal forces which pull nations into integration and centrifugal pull which tend to discourage same (Durkheim, 1968). This is one of the greatest challenges of the Nigerian integration. The component units seem to be getting much more than their contribution to the national coffers, in a very disproportionate manner. This is true of Value Added Tax (VAT). While some states banned the sale of alcohol on religious grounds, they share the proceed from this evil source equitably. The federal Ministry of Finance website and the monthly published allocation figures indicates that Kano has fifty (50) local government areas, the monthly fiscal allocation to this tier of government, outstripped allocation in two states in the South-South zone at the same level of governance. These are states where crude oil the main source of the federal fiscal revenue is derived (Ugoh \& Ukpere, 2010). These challenges to National Integration in Nigeria would be evaluated under the rubrics of fiscal, political, social, economic and miscellaneous factors.

\subsection{Fiscal}

The problem of fiscal federalism has been the strongest centrifugal force that threatens integration in Nigeria. It has become a tool for political bargaining. Dating back to the colonial protectorate period, Lagos and later the southern protectorate have been lending funds to the northern regions to enable them to balance their annual budget (Adedeji, 1969). This had generated some resentment and has continued to do so among the southern political elites till this day. It 
has been asserted that the urge to meet the financial need of the northern protectorate of Nigeria, was the most compelling reason for the amalgamation of Nigeria in 1914 (Adedeji, 1969). The above assertion is further consolidated in the myriads of debates in the Federal House of Representatives during 1960-63 that ended up in the total liquid assets taken over by the new central government on January 1, 1914, in which 93.5 per cent (about £1.7 million) pounds came from the South (Adedeji, 1969). Nevertheless, during the first year of its existence, the country was able to balance its budget. Thus, the solvency of Nigeria during this period was made possible by the favorable revenue position of the colony and southern province (Adedeji 1969). The overt display of these resentments were in 1950s when the northern region had made minimum demand that to continue to be part of the protectorate of Nigeria, there must be equal representation between the North and South in the proposed legislature. It then threatened a break-away if the demand was not met, while in 1959, before the election of that year, it again requested and got the abrogation of the representational equality between the North and the South on the same threat. Consequent upon this, the federal legislature was increased from 181 to 312 and a constituency size delimited on a seat/population ratio of 1:100,000, this gave a constituency distribution of 174 to the north, 73 to the east, 62 to the west and 3 to Lagos. This distribution gave a majority of 36 to the North over the combine total of the East, West and Lagos, (Dudley, 1979). In 1953 it was the turn of the West to do same while the Eastern region took its turn in 1956 and later tried to actualize it through the civil war $1967-70$.

\subsection{Political}

Politically in Nigeria, the 1963 population census which until recently was regarded as the authentic headcount, hence a major determinant of fiscal federalism, asserted that the North has 79.0 per cent of Nigeria's land area, a population figure of 53.5 per cent. The East was 8.3 per cent in area and a population of 22.3 per cent. The West was 8.5 land area, 18.4 of population. The Midwest was 4.2 in land area and 4.6 in populations with Lagos area with 1.2 per cent of the population (Elaigwu, 1983). The above statistics foisted on Nigeria is the 'tyranny of Population' over the Southern part of Nigeria. However, the South by reason of an early head start in the acquisition of Western education, control the governmental bureaucracy. The Southern states by reason of the present of crude oil resources have been agitating for reversal of the revenue sharing structure to the colonially induced revenue allocation formula which was, Derivation $50 \%$, Federal Government 20\%, Equity 30\% to the Distributable Pool Account. This was included in the 1960-63 constitution. In order to enhance integration, equity and justice, it is imperative to eliminate ill-feelings by any group in the nation building processes.

It is instructive to note that, Tell - Magazine (2005, March 7) edition featured one of the last colonial officers in Nigeria by name Harold Smith, who confessed that they inflated the 1963 population census in favor of the North. This conspiracy, has contributed immensely to the crisis of nation building in Nigeria. The 2006 population census figures were based on projection on the 1963 figures because it did not start from zero-base given the revelation of Harold Smith as contained in the above referred 'Tell-Magazine'. According to Sklar and Whitaker (1966), the 1963 census figure indicated that the Northern region had a population of 29 million, East 12 million, West 10 million, and the Midwest 2 million generating a total population of $55,653,821$. It would be recall that population projection according to the United Nations Standard has an annual growth of 2.5 per cent, every ten (10) years. The 2006 population had stated that Nigeria is inhabited by an estimated 140 million persons. It gave the highest number to the North. This has called to question the fact that in Nigeria, the states with fast growing municipal economies, such as Cross River (Calabar), Rivers (Port Harcourt), Lagos State, Delta State (Asaba), has lesser population figures than states with less-developed municipal economies of the north. But judging from the population spread in the states as indicated; the theory of population growth appears to be faulted in Nigeria. There are therefore, other non-economic factors that stimulate population growth. This is because when States such as Jigawa, Bauchi, Benue etc that have less-developed municipal economies outstripping states such as Cross River, Delta, Edo, Akwa Ibom, Bayelsa and Anambra, that have fast growing municipal economies, one would only ponder the factors responsible for such growth (Mofi-News, 2007). It would be recalled that many years ago, Neo-Malthusians had postulated that population growth can also stimulate economic growth because large numbers of persons would increase the labor supply, spur up institutional innovations, enhance technological development and increase the supply of human ingenuity Mofi-News (2007). The question therefore is why has these social developments not taken place in these states which lay claims to high population growth rate? Paradoxically, the north is rather a bastion of poverty as indicated by the data in Table 1 below: 
Table 1: Nigerian Poverty ratio against State Population

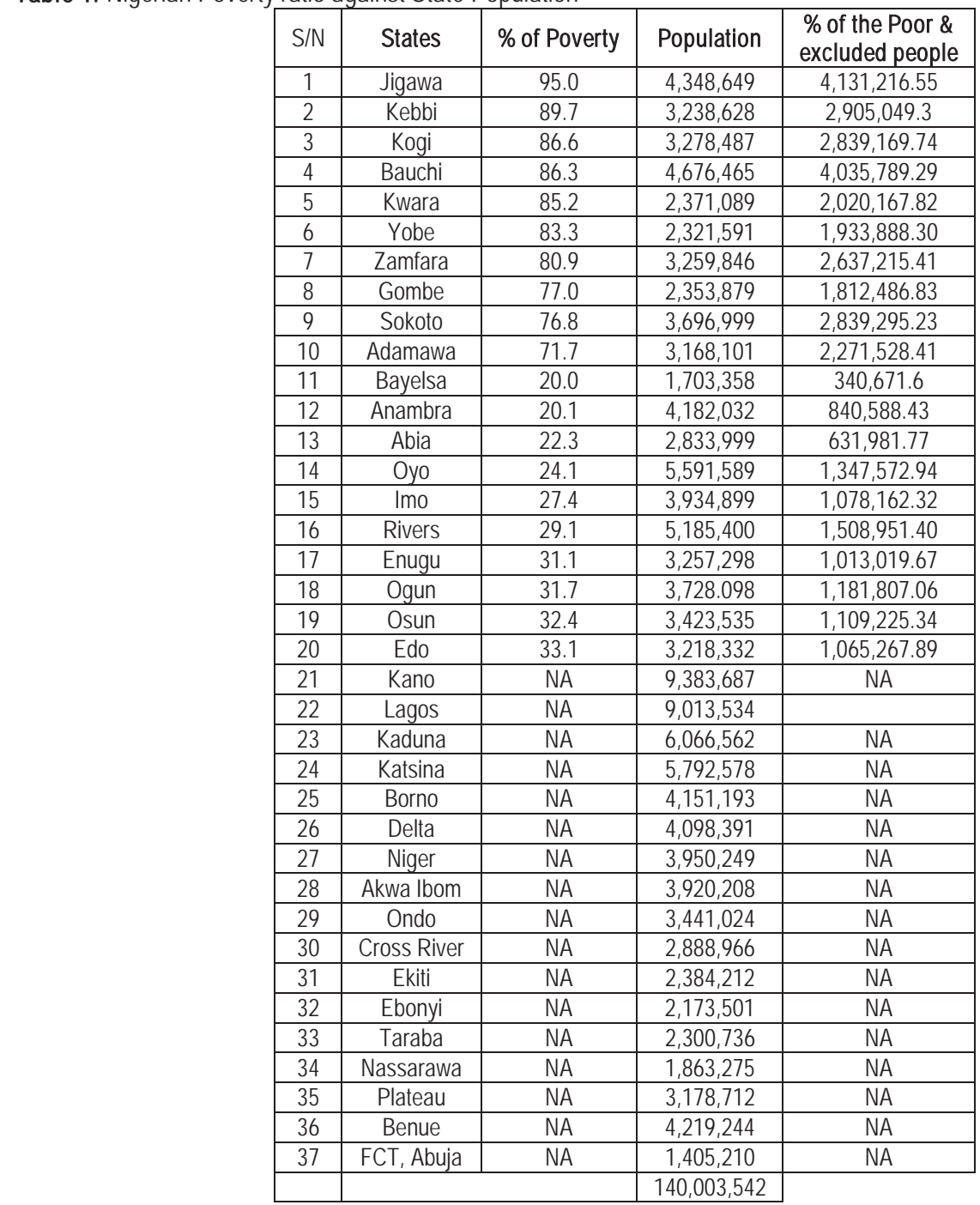

Source: Authors Fieldwork, 2007

\subsection{Social}

Nigeria's greatest hindrance in the march towards becoming an organic state is religious intolerance. The Northerners who are predominantly Muslim are always quick at attacking the Southerners therein. This has led to great movements of southerners from the north. The realization of the anger and readiness of the southerners to promptly response to such attack, has led to 'disguise -personality' of the northerners residing in the south. For instance, an empirical observation by the author in Benin-City, Calabar, Uyo, Port Harcourt (Edo, Akwa Ibom, Cross River and River States ) respectively, indicated that the the northern elements have all abandoned their traditional 'Kaftan and babariga' for jeans and tee/shirts (Author's Fieldwork). Consequently most southerners would deliberately avoid integration with their militant religiously partners. This is compounded by extreme poverty which denies the people education and enlightenment, to see them in an interdependent relationship and thus treat others as they would wish to be treated. A corollary of this is the corruption of the elites which deplete the resources meant for the development of the people according to the Economic and Financial Crime Commission (EFCC).In reference to Table 1, it is not a coincident that the areas with high incident of 
poverty are also areas of security threats in Nigeria.

\subsection{Economic}

There is a perception that some Northerners see the economic power of the country as being in the hands of the Southerners. Hence, they would want to keep the political power at all cost. This is the case of the 'tyranny of population versus the tyranny of economic power. The situation is because the South embraced western education earlier than the North and therefore, was able to occupy the economic structures. In any case, western education has become the most relevant skill required in the modern state. The problematic is that the northern governments would prefer foreign worker to employees from the southern part of Nigeria in their employment. Empirical experiences exist of Southerners who were employed on renewable contract terms in the North. The current state of affairs has made it problematic for Southerners to desire to settle down in the north. This, certainly, is an anti-integration phenomenon.

\subsection{Miscellaneous}

All factors operating against national integration in Nigeria which have not been captured in the categorization above fall within the purview of miscellaneous factors such as the continued corruption of the ruling elites in Nigeria. This includes the problem of leadership vacuum in Nigeria. A Leader with a vision of where to take Nigeria to in the $21^{\text {st }}$ century would have enhanced greater nation-building. However, it no longer a hidden fact that leadership in Nigeria, whether military or civilian, have often been selfish and devoid of good governance. There is certainly no rallying point for all. A National referendum on unity is becoming a necessity if Nigeria is to get more united as a nation. An effective federalism would serve as a balance between centrifugal and centripetal forces.

\section{Prospects for National Integration}

As optimists this paper believes that national integration in Nigeria has bright prospects with the observations of certain normative standards such as:

i) The establishment of a norm which would guarantee access to all the citadel of political offices in the state. For instance when there is an arrangement to ensure that each integrated group would have their turn to produce the President, Governor, Chairman of the Local Government and counselors respectively, this would certainly reinforce the interest of the integrating units towards national integration in Nigeria. This is indeed the answer to majoritarian tyranny.

ii) A genuine commitment to anti-corruption war and the 'due process principles', would be a confidence-building measure towards integration. This would curb tax evasion which denies the government of enormous resources. This is because there are many individuals and corporate organizations which under-value and in extreme cases refuse to pay taxes. Their complaints being that the funds would never be utilized for socio democratic developments, hence, there is no reason to pay taxes.

iii) Leadership has always been a problem in Nigeria, hence Professor Chinua Achebe's epic novel, 'The trouble with Nigeria'. There is an urgent need for a leadership which understands the dynamics of integration and incorporates it into its budget and judiciously implementing same. This would go a long way to build the confidence needed among the people for integration.

iv) The fiscal imbalance in Nigerian federalism, could be addressed using the Pigou thesis, which posited that the costs imposed on one section of the community by another should be the basis of a tax on the beneficiary, which could be re-distributed to compensate those suffering the costs (Pigou, cited in Adedeji, 1966). The problematic of the current situation is that those enjoying the resources do not produce enough, therefore making it difficult to impose taxation to achieve this purpose.

\section{Conclusion}

Nigeria's quest for national integration was given the impetus it needed by the military elite corps. This is partly because the military has dominated Governance for many years. The basic structural reorganization needed to foster national integration was instituted by the military. This also includes steps taken to assuage the fears of the minorities enclosed within the hitherto three major ethnic groups in Nigeria. The immobilize state of national integration in Nigeria is as a 
result of the absence of normative standards and respected by all parties. The institutionalization of such standard should transcend the federal, state, local governments and the ward levels. This is the only way towards the birth of an organic Nigerian state. This problem has lingered because national integration in Nigeria has not been a voluntary process. However given a purposeful leadership and a 'just administration', national integration would produce an organic Nigerian state. However, it should be acknowledge that the journey towards that destination is still a long distance away. Nigeria is still on that part, but a purposeful leadership which is inclining to inputs, would make national integration attainable.

\section{References}

Adedeji A. 1966. 'Nigerian Federal Finance, the Developments Problems and Prospects'. London: Hutchison Educational Ltd.

Almond G and Powell GB 1966..'Comparative Politics: Developmental Approach' Boston: Little Brown

Balassa B 1961. The Theory of Economic Integration. London: Allen \& UnWin.

Burke E and Mistre L 1968.'Cultural Integration' in Encyclopedia of Social (Ed) By David L. Sills vol. 7 \& 8. The Macmillan Company and Free Press

Coleman JS and Roseberg CG 1966. Ed. Political Parties and National Integration In Tropical Africa. Berkeley:University of California

Darah GG 2012. Text of the Inaugural Alex Ibru Legacy Lecture at the University Port Harcourt, Rivers State Nigeria, on Tuesday May 21, 2012, serialized Serialized in the Guardian Newspaper 21-40

Dudley B 1979.'Instability and Crisis in Nigeria -Politics and Crisis in Nigeria'. Ibadan: Ibadan University Press

Durkheim E 1968. .'Organic Solidarity' in Encyclopedia of Social (Ed) By David L. Sills vol. 7 \& 8. The Macmillan Company and Free Press.

Decree No 1 1966. Broadcast to Nigerian by the H. E. Lt. Col. Y. Gowon HFMG and Commander-in-Chief of the Armed Forces, May 27, 1967 cited in J. I. Elaigwu, 'The Military and Political Engineering in Nigeria, 1966-79'. An overview in B. Ikara and Ade Ajayi (ed) Evolution of Political Culture In Nigeria, Ibadan: U. I. Press

Esikot IF 2010. Socio-Political Philosophy - The Basic and the Issues. Uyo: Robert Minders International

Elaigwu J I 1982. ' The Military and Political Engineering in Nigeria, 1966-79' An Overview in B Ikara and Ade Ajayi Ed.

Evolution of Political Culture in Nigeria. Ibadan: University Press

Elaigw J I 1986. GOWON. Ibadan: West Books Publishers Ltd.

Ekundare 0 1975. Economic History of Nigeria 1875-1975. Ibadan: University Press

Jemibewon DM 1998. The Military, Law and Society -Reflection of a General. Ibadan: Spectrum Books Ltd.

Mitrany D 1975. Integration cited in James Lee Ray 1979 Global Politics. Boston: Houghton Mifflin Company.

Mofi-News (2007) 'Population Growth and Economic Development'- January-February (A publication of the Ministry of Finance IncCalabar-Cross River State Vol.6 No. 37

Onwuka R 1982. Development and Integration in West Africa. London: Hutchinson

Ray JL 1979. Global Politics, Boston: Houghton Mifflin Company

Sklar RL and Whitaker CS 1966. Nigeria in Political Parties and National Integration in Tropical Africa Ed. J S Coleman and CG Roseberg, Berkeley: University of California.

Tell-Magazine 2005. 'How Britain Rigged Elections, Census for the North-Former Colonial Officer-Nigeria's Independent Weekly No. 10 March 7, 2005 p 33-39

Ugoh SC and Ukpere WI. 2010. Oil politics and the Niger Delta Developmental Conundrum. African Journal of Business Management, 4(6):1166-1174.

UNECA 2004. Assessing Regional Integration in Africa . Addis Ababa.

Waldo D 1968. Public Administration in the Encyclopedia of Social Sciences edited by David L Sills, The MacMillan Company and New York : the Free Press

Waldo, D. ( 1968) 'Public Administration' in the Encyclopedia of Social Sciences edited by David L. Sills The Macmillan Company and New York: The Free Press 
